\title{
EFFICACY OF E-RECRUITMENT PRACTICES ON EMPLOYEE RETENTION IN MULTINATIONAL CORPORATIONS
}

\author{
Solomon Akpoviroro Kowo', Olusegun Adeleke ObaAdenuga², Olalekan owotutu \\ Sabitu $^{3}$ \\ ${ }^{1}$ Kwara State University Nigeria, Department of Business Administration, kowosolomon@gmail.com \\ ${ }^{2}$ National Open University of Nigeria, Department of Educational Foundation, oadenuga@noun.edu.ng \\ ${ }^{3}$ Ogun State Institute of Technology, Nigeria, Department of Business Administration, olatoyosim@gmail.com
}

\begin{abstract}
Research Purpose. The human resource function of firms is faced with the challenges of identifying recruitment practices that contribute to employee retention as a recruitment outcome. The aim of the study was to examine the relationship between E-recruitment practices and employee retention of multinational corporations (MNCs) in Nigeria.

Design/Methodology/Approach. Two research questions were posed for the study and two hypotheses formulated in line with the objectives. Questionnaires were administered to the selected population of the Unilever Nigeria Plc. Corporate websites and commercial websites sites were the E-recruitment practices used to analysed their influence on employee retention. The data were analysed using manual and electronic based methods through the data preparation grid and statistical package for the social science, (SPSS). The study made use of statistical tools such as regression analysis in testing hypothesis and analysis of variance (ANOVA), which helped in the interpretation of results.
\end{abstract}

Findings The research use analysis to estimate trends that corporate websites and commercial websites were significant in explaining employee retention. The results of this study confirm existing literature that argues for a positive relationship between the two variables. The results also portray that human resource managers should have an understanding of the relationship between E-recruitment practices and employee retention.

Originality/Value/Practical implications. The study seeks to contribute to existing literature on E-recruitment practices and employee retention. The practical justification would be useful to human resource practitioners by making them aware of the current E-recruitment practices and the impact of its implementation to a firm's level of employee retention

Keywords: E-Recruitment; Employee Retention; Corporate Websites; Commercial Websites.

JEL Classification: O15; M51; M15.

\section{Introduction}

The retention of high performing employees is a challenge among firms, making the role that recruitment practices play significant (Trivedi \& Muduli, 2015). In Nigeria and the world at large, internet usage has become norm and therefore, to attract a good number of applicants, an organisation's best resolve should be to use the internet. The process of recruitment has changed enormously by using the internet technology. It is increasingly being used by both large and small organisations, and it is becoming a favoured medium of both employers and job seekers (Daft, 2000, Kuhn, 2000). The management of recruitment process is made easy through online interview scheduling as the organization have immediate access to application of candidates and the shortlisting of qualified candidates is made easier and faster as any candidate who does not meet the desired qualification of the organisation will be dropped automatically by the system. In addition, there is an automatic correspondence between the organisation and applicant, which makes it easy to get information from the applicant. 
This study, therefore, seeks to identify the influence of E-recruitment practices on employee retention, especially amongst multinational corporations. Focus on E-recruitment is based on the fact that it is a practice that is increasingly being adopted by human resource managers with a long-term goal of achieving competitive advantage through its contribution to the retention of rare and valuable talent. Erecruitment practices are multidimensional and have been identified as corporate websites, commercial websites/job boards and social network sites (Lee, 2005; Girard \& Fallery, 2009; Sills, 2014; Kaur, 2015). Corporate websites are web-enabled interface that are used for E-recruitment through the use of a career portal that aims at brand promotion whilst commercial websites are independent of an employer, which gives companies the possibility of outsourcing their recruitment function (Maurer \& Liu, 2007).

The study is anchored on the resource based view (RBV) of the firm to explain the value of talent to an organisation. This study aims to identify E-recruitment practices relevant to multinationals and their influence on employee retention. The existence of numerous E-recruitment practices show that employers need to identify the specific practices relevant to their firm in order to acquire and retain rare talent that is considered as a scarce resource that organisations require for competitive advantage (Madia, 2011; Akio, 2005). This study, therefore, aims to identify the E-recruitment practices relevant to multinational corporations in Nigeria and their impact on employee retention. This research seeks to answer the following research questions: (i) What is the relationship between corporate websites and employee retention in multinational corporations in Nigeria? (ii) What is the relationship between commercial websites and employee retention in multinational corporations in Nigeria?

Objectives of the Research are (i) to examine the influence of corporate websites on employee retention of multinational corporations in Nigeria, and (ii) to analyse the influence of commercial websites on employee retention of multinational corporations in Nigeria.

\section{Literature Review}

Recruitment comprises all the practices that are carried out by an organisation to acquire human capital through the identification and attraction of employees (Baum \& Kabst, 2014). Its purpose is to ensure that acquired recruits remain in a firm for the maximum possible time to contribute to the achievement of overall organisation goals through employee retention (Galanaki, 2002). This is because the ability of a firm to retain talent is considered a source of competitive advantage in addition to enhancing organisational performance (Mahal, 2012). The term E-recruitment has been interchangeably used with online recruitment, electronic recruitment, web-based recruitment and cyber recruitment (Greengard, 2012; Chew, 2004).

Scholars within the human resource field have defined E-recruitment in various ways, which include: the process of acquiring talent online (Allden \& Harris, 2013); the formal sourcing of job information online (Galanaki, 2002); the use of online technology to acquire talent either through corporate or third party recruiters (Rao, 2011); an online process of attracting suitable candidates via electronic means (Malik \& Razaullah, 2013); and the use of the internet to identify and attract potential employees (Breaugh \& Starke, 2000). Talent acquisition in this case is the strategic approach to on board individuals with skills and competencies to efficiently and effectively meet dynamic business needs (Slovensky \& Rose, 2012; Mbugua et al, 2013).

Even though this definition is employer oriented, as expressed by the presented literature, it is noticeable that E-recruitment may include an element of job seekers seeking opportunities online (Avebrook, 2012; Madia, 2011; Lee, 2005; Allden \& Harris, 2013). Commercial websites allow companies to communicate their vacancies to a large audience; Web 2.0 provides tools that allow for sharing of content such as blogs that may be created by employers or head-hunters, social networks such as LinkedIn and Facebook that offer employer job seeker interaction, Real Simple Syndication (RSS) feeds where information on updated job offers are uploaded onto search engines and video platforms such as YouTube whereby video curriculum vitas can be presented (Boyd \& Ellison, 2008).

E-Recruitment practices may, therefore, be classified as; corporate websites, commercial websites and social network sites (Lee, 2005; Parry \& Tyson, 2008; McDonnell et al, 2010; Lakshmi, 2013; Sills, 2014; Kaur, 2015 ; Aktor, 2011; Smith \& Rupp, 2004; Mukana, 2016). The adoption of E-recruitment 
practices is often favoured by multinationals in such economies in order to reach a wider scope, as not only is it difficult to acquire talent but also to get expatriates to move to such economies (Trivedi \& Muduli, 2015; Fondeur, 2006). In order to cultivate competencies and skills of the local job market, multinationals develop graduate trainee programmes whereby the use of E-recruitment practices is effective in screening graduates who can undergo entry-level training and potentially be absorbed by the firm (Peltokorpi \& Froese, 2015; Mbugua, Waiganjo \& Njeru, 2013; Boyd \& Ellison, 2008; Girard \& Fallery, 2009; Gazzawi and Accoumeh, 2014).

Levels of Employee Retention in Multinational Corporations: Retention occurs as a result of voluntary practices carried out by an organisation (Chew, 2004) to create an environment that would engage their employees on a long-term basis or to the extent to which their contracts state (Allen, Bryant \& Vardaman, 2010). Skilled employees have, therefore, become a major factor that differentiates firms, as their expertise has the potential to provide competitive advantage within international markets (Chiminade, 2007; Mbugua, Waiganjo \& Njeru, 2015). Voluntary turnover is when an employee exits the firm under their own terms, commonly caused by job dissatisfaction and old age, whereas involuntary turnover is when an employee is removed from duty by the firm's management through promotions, shift to other department(s) or expulsion from duty by senior management (Cappelli, 2001; Malik \& Razaullah, 2013 ; Koo \& Wati, \& Jung, 2012 ; Rao, 2011). Employee retention with regard to early work adjustment is dependent on the recruitment practices that better prepare employees for early work experience compared to other practices (Reilly, Brown, Blood \& Malatesta, 1981; Mahal, 2012)

Influence of E-Recruitment Practices on Employee Retention: Kashyap and Rangnekar (2014) concluded that the source through which employees are obtained are usually closely tied to the type of job opening because persons recruited through certain sources would have more accurate information about the background of the company and job information (Rogers, 2015). Applicants are, therefore, able to make informed decisions whether to proceed with the application for a job. Mbugua, Waiganjo and Njeru (2015) found that the use of strategic employee recruitment influenced employee retention through the use of associations, psychometric tests, website, targeting specific professionals and utilisation of technologies.

The information that a company presents through their E-recruitment platforms communicates the job detail expectations to potential recruits, which greatly influence the decision to apply for a job and, hence, the length of stay within that particular job with high chances of employee retention (Trivedi \& Muduli, 2015; Peltokorpi \& Froese, 2015; Kashyap \& Rangnekar, 2014). Job analysis, comprising detailed descriptions and specifications of a job vacancy, and the means through which a job vacancy is communicated are the major determinants of the levels of employee retention a firm will return from the candidates who will be hired (Sills, 2014; Masese \& Kinange, 2016; Trivedi \& Muduli, 2015; Fondeur, 2006).

Influence of Corporate Websites on Employee Retention: Different schools of thought have been found with regard to the use of corporate websites and their relationship to employee retention. Some have demonstrated the existence of a positive relationship and the absence of a relationship. Through a study focused on higher education institutions, the use of E-recruitment as a human resource information system contributes to employee retention through profiling personnel by analysing their strengths and weaknesses (Rogers, 2015). In addition, Rogers argued that the use of human resource information system enables the business unit to strategically plan on human resource activities that maximise employee retention (Pollitt, 2007; Nwasha, 2013; Trivedi \& Muduli, 2015; Rogers, 2015) Besides the use of corporate websites having a positive relationship with employee retention, some research has observed the absence of a relationship between the two as E-recruitment has been found to be a practice that only provides advantages such as large geographical access of potential employees, time and cost effectiveness, ease of access to candidates with additional skills in computing, ease of use and faster response time to job vacancy postings (Galanaki, 2002; Cappelli, 2001; Mukuna, 2016).

Influence of Commercial Websites on Employee Retention: Commercial websites may take form of independent firms or consultants. Depending on the nature of a firm, commercial website owners could either act as a hiring consultant, recruit on behalf of an employer for a fee and post jobs on their website without approval by employers or partake in both the business of recruitment consultants and job boards 
for any employer (Lee, 2005). Scholarly articles reviewed have revealed the existence of a positive relationship between the use of commercial websites and employee retention. The use of commercial websites to outsource the human resource recruitment function of a firm allows for the multiple screening of candidates by both the recruiting firm and the employer. The use of commercial websites such as Bayt.com equips recruiters with superior tools to filter through such passive candidates and acquire those that best fit their firm, hence, higher chances of being able to retain such employees whose skills match organisational needs (Lee, 2005). Commercial websites tend to disclose the compensation policies that employers are offering for specific job openings (Masese \& Kinange, 2016; Smith \& Rupp, 2004; Galanaki, 2002; Allden \& Harris, 2013). The impact of disclosing a firm's compensation details should, therefore, be considered by commercial website owners, based on whether or not the employer wants the details to be presented, with knowledge on the potential implications (Masese \& Kinange, 2016; Venkatesh et al, 2003).

Resource Based View of the firm: The (RBV) of the firm argues that the attainment and retention of sustainable competitive advantage is derived from a firm's resources and capabilities (Penrose, 1959). Even though similarities in human resource practices may cut across various organisations within a particular market, firm-specific resources and needs develop over time, creating uniqueness that may not be easy to imitate. The theory applied to the study seeks to extend the RBV of the firm to Erecruitment practices and tries to explore its linkages to employee retention. Through the development of the capabilities of E-recruitment, its antecedents and outcomes, the firm can stay ahead of its competitors (Rogers, 2015), hence, leading to (VRIN) valuable, rare, non-imitable and nonsubstitutable. creating internal firm capabilities that are not easy for other firms to imitate (Barney, Wright \& Ketchen, 2001). This provides humble resource systems with the potential to contribute to competitive advantage that is sustainable through the development of firm and specific human resource competencies. It is for this reason that talent, which is a scarce resource, is an element that organisations globally compete for to reflect back on their goals and competitive advantage within the markets they operate in. This theory is relevant to the study because it demonstrates how a firm derives sustainable competitive advantage through the exploitation of the scarce characteristics of individuals who are talented.

\section{Methodology}

This research adopted the survey research, the experimental research, and the expo factor method was adopted. Data were obtained through the use of questionnaire. The questions were designed in simple and clear language to remove ambiguity. The responses to each statement will also be based on a 5point Likert ordinal scale. The responses generated through the questionnaire assisted the researcher to address the research problem, objectives, questions and hypothesis (Easterby et al, 2011). The population of this study was limited to human resource managers of Unilever Nigeria PLC, Lagos state, Nigeria. For this study, the sample size was determined using Marl Slovin formula. This formula is considered with applying a normal approximation with a confidence level of $95 \%$ and a limit of tolerance level (error level) of 5\%.

The technique used for selecting the sample for this study is simple probability sampling technique.

Primary and secondary data are obtained and used for this study. Questionnaire was used as an instrument and structured through the specific objectives of this study, and the degree of responsiveness of the respondents was measured on a 5-piont Likert scale of strongly agree $(\mathrm{SA})=5$, agree $(\mathrm{A})=4$, undecided $(\mathrm{U})=3$, strongly disagree $(\mathrm{SD})=2$, and Disagree $(\mathrm{D})=1$. The data were analysed using manual and electronic based methods through the data preparation grid and statistical package for the social science, (SPSS). The study made use of the descriptive analysis to achieve the mean, frequency distribution and percentage result of the research work (Creswell, 2009). The study used statistical tools such as regression analysis in testing hypothesis and ANOVA, which helped in the interpretation of results. 
Table 1. Distribution of respondents and response rate (Source: author's own compilation 2018)

\begin{tabular}{|c|c|c|}
\hline Respondents Occupation & $\begin{array}{c}\text { Questionnaire Administered } \\
\text { (sampled) }\end{array}$ & Percentage of Total Response (\%) \\
\hline Top level & 10 & 90.9 \\
\hline Middle level & 1 & 9.1 \\
\hline Lower level & - & - \\
\hline Total & 11 & 100.0 \\
\hline Gender/category & $\begin{array}{l}\text { Questionnaire administered } \\
\text { (sampled) }\end{array}$ & Percentage of total response $(\%)$ \\
\hline Male & 9 & 81.8 \\
\hline Female & 2 & 18.2 \\
\hline No. of returned & 11 & 100 \\
\hline No. of not returned & 0 & 0 \\
\hline Total no. of questionnaires & 11 & 100 \\
\hline
\end{tabular}

The research questionnaire was administered to (11) respondents (Human resource managers), which is the sample size representing the study population of the firms. Eleven questionnaires, representing $100 \%$ were returned. The table above shows the details at a glance. The findings reveal that nine respondents, representing $81.8 \%$, were male and two respondents, representing $18.2 \%$, were female. This implies that majority of the respondent were male. Unilever Nigeria PLC, Lagos state, Nigeria, has only two female human resource managers.

The study revealed that five respondents, representing $45.5 \%$, had 5 years of working experience and six respondents, representing 54.5\%, had between 6 and 10 years' work experience. This implies that majority of the respondent had between 6 and 10 years of working experience. On the basis of management category, it was revealed that 10 respondents, representing $90.9 \%$, were top level managers and one respondent, representing $9.1 \%$ was, middle level manager. This implies that majority of the respondent were top-level managers. More so, the findings of educational qualification of the respondents revealed that 11 respondents were MBA/Bsc holders. The respondents were classified based on their age difference, and the findings show that four respondents, representing $36.4 \%$, were aged between 21 and 30 years, five respondents, representing $45.5 \%$, between 31 and 40 years; and two respondents, representing $18.2 \%$, between 41 and 50 years. This implies that majority of the respondent were between 31 and 40 years.

Table 2. Descriptive statistics of E-recruitment practices on employee retention of multinational corporations. (Source: Author's own compilation 2018)

\begin{tabular}{|l|c|c|}
\hline Responses & Total (N) & Mean \\
\hline Corporate Websites and Employee Retention of MNCs & 100 & 3.46 \\
\hline $\begin{array}{l}\text { The organisation has a company website that has company information and history, } \\
\text { which promotes its brand }\end{array}$ & 100 & 2.89 \\
\hline $\begin{array}{l}\text { The organisation has a company website that has information on product/service } \\
\text { offering, which promotes its brand }\end{array}$ & 100 & 3.68 \\
\hline $\begin{array}{l}\text { The organisation website has a recruitment portal that provides candidates with } \\
\text { relevant job information. }\end{array}$ & & \multirow{2}{*}{} \\
\hline
\end{tabular}




\begin{tabular}{|l|c|c|}
\hline $\begin{array}{l}\text { Candidates can view updates on the progress of their applications through their } \\
\text { accounts on the recruitment portal. }\end{array}$ & 100 & 3.85 \\
\hline $\begin{array}{l}\text { Managers are involved in the final online reviewing and screening of qualified } \\
\text { candidates before interviews are held. }\end{array}$ & 100 & 3.39 \\
\hline Commercial Websites and Employee Retention of MNCs & Total & Mean \\
\hline Commercial website owners conduct screening tests to ensure employer legitimacy & 100 & 3.45 \\
\hline $\begin{array}{l}\text { The organisation is involved in the short listing of candidates obtained through commercial } \\
\text { websites before job assignment }\end{array}$ & 100 & 3.57 \\
\hline $\begin{array}{l}\text { The online recruitment agency possesses screening tools that filter candidates before } \\
\text { they are sent to the organisation for job assignment }\end{array}$ & 100 & 2.99 \\
\hline $\begin{array}{l}\text { The organisation is involved in the final recruitment of candidates obtained through } \\
\text { commercial websites before job assignment }\end{array}$ & 100 & 3.73 \\
\hline $\begin{array}{l}\text { The organisation is aware that its job vacancy information could be found on other } \\
\text { websites without its consent }\end{array}$ & 100 & 3.89 \\
\hline \begin{tabular}{l} 
The organisation outsources the recruitment function to online recruitment agencies \\
\hline
\end{tabular} & 100 & 3.79 \\
\hline
\end{tabular}

\section{Results}

Hypothesis One

Ho: Corporate Websites does not influence Employee Retention of Multinational Corporations in Nigeria.

Hi: Corporate Websites influence Employee Retention of Multinational Corporations in Nigeria.

Table 3. Model Summary (Source: author's own compilation)

\begin{tabular}{|l|r|r|r|r|r|}
\hline Model & R & R Square & \multicolumn{1}{|c|}{$\begin{array}{c}\text { Adjusted R } \\
\text { Square }\end{array}$} & $\begin{array}{l}\text { Std. Error of the } \\
\text { Estimate }\end{array}$ & Durbin-Watson \\
\hline 1 & .838 & .702 & .669 & .465 & 2.313 \\
\hline
\end{tabular}

Predictors: (Constant), Corporate Websites

Dependent Variable: Employee Retention

The result from the model summary table revealed the extent to which the variance in Employee Retention can be explained by Corporate Websites is $83.8 \%$ i.e. ( $\mathrm{R}$ square $=0.838$ ). The ANOVA table shows the Fcal 21.251 at 0.000 significance level.

Table 4. ANOVA (Source: author's own compilation)

\begin{tabular}{|l|l|r|r|r|r|r|}
\hline \multicolumn{2}{|l|}{ Model } & Sum of Squares & \multicolumn{1}{c|}{ Df } & Mean Square & F & Sig. \\
\hline 1 & Regression & 4.598 & 1 & 4.598 & 21.251 & .001 \\
\cline { 2 - 7 } & Residual & 1.9 & 9 & .216 & & \\
\cline { 2 - 7 } & Total & 6.545 & 10 & & & \\
\hline
\end{tabular}


Table 5. Coefficients (Source: author's own compilation 2018)

\begin{tabular}{|l|l|r|r|r|r|r|}
\hline \multicolumn{2}{|l|}{ Model } & \multicolumn{2}{|c|}{ Unstandardized Coefficients } & $\begin{array}{c}\text { Standardized } \\
\text { Coefficients }\end{array}$ & \\
\cline { 3 - 7 } & B & Std. Error & Beta & \multicolumn{1}{c|}{ t } & Sig. \\
\hline 1 & (Constant) & 2.842 & 2.996 & & .949 & .368 \\
\cline { 2 - 7 } & Corporate Websites & .816 & .177 & .838 & 4.610 & .001 \\
\hline
\end{tabular}

Dependent Variable: Employee Retention

The coefficient table above shows that the simple model that expresses how Corporate Websites affects Employee Retention. The model is shown mathematically as follows: $\mathrm{Y}=\mathrm{a}+\mathrm{bx}$ where $\mathrm{y}$ is Employee Retention process and $\mathrm{x}$ is Corporate Websites, $\mathrm{a}$ is a constant factor and $\mathrm{b}$ is the value of coefficient. From this table therefore, Employee Retention $=2.842+0.816$ Corporate Websites. This means that for every $100 \%$ Employee Retention, Corporate Websites 81.6\%. The significance level below 0.01 implies that a statistical confidence of above $99 \%$. Since our $\mathrm{P}$ value ( 0.005 is greater than the calculated value), Thus, the decision would be to reject null hypothesis (Ho), and accept the alternative hypothesis (H1) which implies that Corporate Websites influences Employee Retention.

Hypothesis Two

Ho: Commercial Websites does not affect employee retention in multinational corporations in Nigeria

Hi: Commercial Websites affect employee retention in multinational corporations in Nigeria

Table 6 .Model Summary (Source: author's own compilation)

\begin{tabular}{|l|r|r|r|r|r|}
\hline Model & $\mathrm{R}$ & R Square & Adjusted R Square & $\begin{array}{c}\text { Std. Error of the } \\
\text { Estimate }\end{array}$ & Durbin-Watson \\
\hline 1 & .446 & .199 & .170 & .638 & .320 \\
\hline
\end{tabular}

Predictors: (Constant), Commercial Websites

Dependent Variable: Employee Retention

The result from the model summary table revealed the extent to which the variance in Employee Retention can be explained by Commercial Websites is $44.6 \%$ i.e. ( $\mathrm{R}$ square $=0.446$ ). The ANOVA table shows the Fcal 6.937 at 0.000 significance level.

Table 7. ANOVA (Source: author's own compilation)

\begin{tabular}{|l|l|r|r|r|r|r|}
\hline \multicolumn{2}{|l|}{ Model } & Sum of Squares & Df & Mean Square & F & \multicolumn{1}{c|}{ Sig. } \\
\hline \multirow{3}{*}{1} & Regression & .393 & 1 & .393 & 6.937 & .000 \\
\cline { 2 - 7 } & Residual & .440 & 28 & .301 & & \\
\cline { 2 - 7 } & Total & .833 & 29 & & & \\
\hline
\end{tabular}


Table 8. Coefficients (Source: author's own compilation)

\begin{tabular}{|c|c|c|c|c|c|c|}
\hline \multirow{2}{*}{\multicolumn{2}{|c|}{ Model }} & \multicolumn{2}{|c|}{ Unstandardized Coefficients } & \multirow{2}{*}{$\begin{array}{c}\begin{array}{c}\text { Standardized } \\
\text { Coefficients }\end{array} \\
\text { Beta }\end{array}$} & \multirow[b]{2}{*}{$\mathrm{t}$} & \multirow[b]{2}{*}{ Sig. } \\
\hline & & $\mathrm{B}$ & Std. Error & & & \\
\hline \multirow[t]{2}{*}{1} & (Constant) & .772 & .225 & & 4.181 & .000 \\
\hline & $\begin{array}{l}\text { Employee } \\
\text { Retention }\end{array}$ & .667 & .961 & .446 & 2.634 & .004 \\
\hline
\end{tabular}

Dependent Variable: Commercial Websites

The coefficient table above shows that the simple model that expresses how Commercial Websites affects Employee Retention. The model is shown mathematically as follows: $\mathrm{Y}=\mathrm{a}+\mathrm{bx}$ where $\mathrm{y}$ Employee Retention and $\mathrm{x}$ is Commercial Websites, $\mathrm{a}$ is a constant factor and $\mathrm{b}$ is the value of coefficient. From this table therefore, Employee Retention $=0.772+0.667:$ Commercial Websites. This means that for every $100 \%$ of Employee Retention, Commercial Websites contributed $66.7 \%$. The significance level below 0.01 implies that a statistical confidence of above $99 \%$. Since our P value $(0.005$ is greater than the calculated value), Thus, the decision would be to reject null hypothesis (Ho), and accept the alternative hypothesis (H1) which implies that Commercial Websites affects Employee Retention

\section{Discussion of findings}

Descriptive analysis showed that corporate websites were the most relevant E-recruitment practice and including firm information was its most relevant feature. However, majority of firms under study with corporate websites did not allow candidates to view the progress of their applications. Multiple regressions were performed to assess the relationship between corporate websites and employee retention. Corporate websites were significant in explaining self-selection and early work adjustment. Research has shown that corporate websites could have either a positive relationship (Mukuna, 2016; Peltokorpi et al., 2015) or no relationship with employee retention (Capelli, 2001). The results of this study confirm the existing literature that argues for a positive relationship between the two variables. We can, therefore, conclude that corporate websites are the key E-recruitment practices adopted and the success of its use lies on the firm's ability to provide information about their history, vision and mission and product offering.

This finding further confirms the importance of a firm's reputation and core values in the attraction of talent. As corporate websites were significant in explaining self-selection and early work adjustment, their use should be reinforced by developing employee skills. Moreover, Descriptive analysis indicated that commercial websites were also relevant to employee retainment in multinational corporations. However, analysis showed that commercial website of MNCs is significant in explaining the levels of employee retention. The results obtained from this study correspond with the literature that Erecruitment practice is significant in explaining the level of employee retention (Lee, 2005; Smith \& Rupp, 2004; Masese \& Kinange, 2016). The findings will be an immense benefit in gaining opportunity for jobs to be advertised in global, local and niche market; verified and technically good candidate; and reduced cost compared to print advertisement. To the applicants, it provides a wide range of job opportunities, quick and easy access to information on job opportunities.

\section{Conclusions}

Corporate websites and commercial websites sites were the E-recruitment practices used to analyse the influence of employee retention in this research. The results showed that corporate websites and commercial website were significant in explaining employee retention. The retention of high performing employees is a challenge amongst firms, making the role that recruitment practices play significant. 
Compared to other employee retention management practices, recruitment practices are the foundation to the quality of new recruits absorbed by a firm and, to a greater extent, signifies the level of employee retention by a firm. The adoption of E-recruitment practices is often favoured by multinationals in such economies in order to reach a wider scope, as not only is it difficult to acquire talent but also to get expatriates to move to such economies. In conclusion, commercial websites is relevant in explaining employee retention because results indicate that firms are aware that information on their job vacancies can be found on commercial websites. These, however, guarantee that they outsource their recruitment function to commercial websites.

The practical justification of this study would be useful to human resource practitioners by making them aware of current E-recruitment practices and the impact of its implementation to a firm's level of employee retention.

On the basis of the result of findings, the study recommends that human resource managers should have an understanding of the relationship between E-recruitment practices and employee retention to gain competitive advantage. E-recruitment is based on the fact that it is a practice that is increasingly being adopted by human resource managers with a long-term goal of achieving competitive advantage through its contribution to the retention of rare and valuable talent. The sample size for this research was determined using Marl Slovin formula.

The limitation of study: Using an alternative method for the sample size determination may offer a different sample size. It is important to note that this research engaged a very small sample population for enclosing the possibility of generalisation. Furthermore, this study relied on self-report measures, which can potentially lead to subjective bias amongst the respondents. It may have been difficult to provide the objective level as most firms are more concerned with employees who are retained and how to retain them rather than those who have already terminated their employment contracts.

Future Research: (i) The quantitative aspect of this research adopted a survey method of data collection; other studies could consider carrying out a study involving a longitudinal data collection process to provide a reliable confirmation of the relationships identified in this research. (ii) For this research, the quantitative research design was used. This design is such that numerical data were generated from a number of questionnaires administered to several respondents. Further studies could use in-depth interviews as qualitative data collection process to enrich the data collection process.

\section{References}

Akio, T. (2005). The Critical Assessment of the Resource-Based View of Strategic Management:

The Source of Heterogeneity of the Firm. Ritsumeikan International Affairs, 3, 125-150.

Aktor. (2011). Interactive Market Report on European Job Sites 2011/ 2012 (No. 7).

Allden, N., \& Harris, L. (2013). Building a positive candidate experience: towards a networked model of E recruitment. Journal of Business Strategy, 34(5), 36-47.

Allen, D., Bryant, P., \& Vardaman, J. (2010). Retaining Talent: Replacing Misconceptions with Evidence-based Strategies. Academy of Management, 24(2), 48-64.

Avebrook, J. (2012). Integrating Performance Management and HRIS. Journal of Management Information Systems, 7(8), 25-38.

Barney, J., Wright, M., \& Ketchen, D. (2001). The resource-based view of the firm: Ten years after 1991. Pergamon, Journal of Management, (27), 625-641.

Baum, M., \& Kabst, R. (2014). The Effectiveness of Recruitment Advertisements and Recruitment Websites. Human Resource Management, 53(3), 353-378.

Boydell, M. (2002). Internet recruitment helps HR careers. Canadian HR Reporter, 11(20), 5.

Boyd, M., \& Ellison, B. (2008). Social network sites: Definition, history and scholarship. Journal of ComputerMediated Communication, 13(1), 210-230.

Cappelli, P. (2001). The most of on-line recruiting. Harvard Business Review, 79(3), 139-146. 
Chaminade, B. (2007). A retention checklist. Retrieved from www.hrmagazine.co.au

Chew, J. (2004). The influence of Human Resource Management Practices on the Retention of Core employees of Australian Organizations: An empirical study. Murdoch University.

Creswell, J. W. (2009) 'Educational research Planning, conducting and evaluating quantitative and qualitative research'. (2 $\left.2^{\text {nd }} E d\right)$ Upper Saddle River, N.J: Pearson Education.

Easterby-Smith, M., Thorpe, R.,\& Jackson, P.R. (2011) 'Management Research'. 3rd Eds, London, SAGE Publications

Fondeur, Y. (2006). Online recruitment: the transparency dilemma. Personnel, 472, 46-48.

Galanaki, E. (2002). The decision to recruit online. Career Development International.

Gazzawi, K., \& Accoumeh, A. (2014). Critical success factors of the e-recruitment system. Journal of Human Resources Management and Labor Studies, 2(2), 159-170.

Girard, A., \& Fallery, B. (2009). E-recruitment: new practices, new issues. An exploratory study. Human Resource Information System, 33-39.

Greengard, S. (2012). Picking-and keeping-the cream of the crop: Smart strategies are needed for both recruitment and retention of talent. HRM International Digest, 20(3), 26-29.

Holm, A. (2012). E-recruitment: Towards an Ubiquitous Recruitment Process and Candidate Relationship Management. German Journal of Research in HRM, 26(3), 241-259.

James A. Breaugh and Mary Starke (2000) Research on Employee Recruitment: So Many Studies, So Many Remaining Questions. Journal of Management 2000, Vol. 26, No. 3, 405-434

Kashyap, V., \& Rangnekar, S. (2014). The impact of employee retention practices on employee's turnover intentions. South Asian Journal of HRM, 1(2), 221-247.

Kaur, P. (2015). E-recruitment: A conceptual study. International Journal of Applied Research, 1(8), 78-82.

Koo, C., Wati, Y., \& Jung, J. (2012). Making social media join the workforce: Technologies can play a big part if businesses do their homework. Strategic Direction, 28(6), 567-580.

Lakshmi, S. (2013). E-Recruitment: A boom to the organizations in the competitive world. Journal of Business and Management, 25-28.

Lee, I. (2005). The Evolution of E Recruiting: A Content Analysis of Fortune 100 Career Websites. Journal of Electronic Commerce in Organizations, 3(3), 57-68.

Mack (2010). The philosophical underpinnings of educational research. Polyglossia, 19, 5-11.

Madia, S. (2011). Social media as a recruitment strategy. Strategic HR Review, 10(6), 19-24.

Mahal, P. (2012). HR practices as determinants of organizational commitment and employee retention. The IUP Journal of Management Research, 11(4), 37-53.

Malik, Z., \& Razaullah, D. (2013). The role of E-recruitment Towards Attraction of Workforce: A Case of Telecom Sector Organization. Abasyn Journal of Social Sciences, 6(1), 104.

Masese, F., \& Kinange, U. (2016). Effectiveness of E-Recruitment in Organization Development. Management and Economic Journal, 5, 272-282.

Maurer, S., \& Liu, Y. (2007). Developing effective e-recruiting websites: Insights for managers from marketers. Business Horizons, 50, 305-314.

Mbugua, G., Waiganjo, E., \& Njeru, A. (2013). Relationship between Strategic Recruitment and Employee Retention. International Journal of Business Administration, 6(1), 87-97.

McDonnell, A., Gunnigle, P., \& Lavelle, J. (2010). Learning transfer in multinational companies. Human Resource Management Journal, 20(1), 23-43.

Mukuna, A. (2016). Strategic responses to investment shocks by selected multinational corporations in Kenya. University of Nairobi.

Nwasha, N. (2013). An Over-view of Online Recruitment: The Case of Public and Private Sectors in Tanzania. European Journal of Business and Management, 5(32), 11-21. 
Parry \& Tyson. (2008). The use and success of online recruitment methods. HRM Journal, 18(3).

Peltokorpi, V., \& Froese, F. (2015). Recruitment source practices in foreign and local firms: a comparative study in Japan. Journal of Human Resources, 54(4), 421-444.

Penrose. (1959). The theory of the growth of the firm. New York: Wiley.

Perlmutter. (1969). The tortuous evolution of the MNC. Columbia Journal of WB, 4, 9-18.

Pollitt, D. (2007). E-recruitment to improve talent management. HRM Digest, 15(4), 26-28.

Rao, P. (2011). E recruitment in emerging economies. Marymount University.

Reilly, R., Brown, B., Blood, M., \& Malatesta, C. (1981). The effects of realistic previews: A study and discussion of the literature. Personnel Psychology, 34, 823-834.

Rogers, E. (1962). Diffusion of innovations (1st ed.). New York: Free Press of Glencoe.

Rogers, W. (2015). Using Social Media in the Recruitment Process. insight series.

Sills, M. (2014). E recruitment: traditional recruitment and the influences of social media: A qualitative and quantitative review. Metropolia University of Applied Sciences.

Slovensky, R., \& Ross. (2012). Use of social media to screen job applicants. Info, 14(1), 55-69.

Smith, A., \& Rupp, W. (2004). Managerial challenges of e-recruiting: extending the life cycle of new economy employees. Online Information Review, 28(1), 61-74.

Trivedi\& Muduli. (2015). Research on Recruitment Outcomes and Recruitment methods. International Journal of Advancement in Engineering and Management, 2(9).

Venkatesh, V., Morris, G., Davis, G., \& Davis, F. (2003). User Acceptance of Information Technology: Toward a Unified View. MIS Quarterly, 27(3), 425-478. 